\title{
Journal of Applied Food Technology
}

Home page : https://ejournal2.undip.ac.id/index.php/jaft

\section{The Antioxidant Activity of Yogurt Drink by Mangosteen Rind Extract (Garcinia mangostana L.)}

\author{
Jeki Mediantari Wahyu Wibawanti ${ }^{1}{ }^{*}$ Zulfanita $^{1}$, Dedi Runanto ${ }^{2}$ \\ ${ }^{1}$ Animal Science Department, Faculty of Agriculture, Muhammadiyah University of Purworejo, Central Java, \\ Indonesia \\ ${ }^{2}$ Management Department, Faculty of Economic, Muhammadiyah University of Purworejo, Central Java, \\ Indonesia
}

*Corresponding author (jekiwibawanti@gmail.com)

\begin{abstract}
Yogurt drink can be produces from goat milk. Yogurt drink was added mangosteen rind extract to increase quality of product. This study aimed to determine antioxidant activity (total phenol compound, antioxidant activity by $I_{50}$ and thiobarbituric acid or TBA value) of yogurt drink from goat milk by mangosteen rind extract. Complete randomized design was used in this research with 4 treatments and 5 replications. The antioxidant activities of yogurt supplemented with $0,1,2$, and $3 \%(\mathrm{v} / \mathrm{v})$ mangosteen rind extract was analysed. The result shows that the total phenol content increased along the increase in the levels of mangosteen. Yogurt drink with mangosteen had radical higher scavenging activity than control. TBA value showed significant differences $(p<0.05)$ among treatments. As conclusion, mangosteen rind extract had the potential to improve antioxidant and hinder the rancidity in yogurt drink.
\end{abstract}

Article information: Received: 30 January 2019 Accepted:14 April 2019

Available online: 02 May 2019

Keywords:

Antioxidant

goat milk

mangosteen rind phenol

yogurt drink

(c) 2019

Indonesian Food Technologists

This is an open access article under the CC BY-NC-ND license

doi: 10.17728/jaft.4267

\section{Introduction}

Goat milk is known to have unique characteristics that contains higher proportion of fat than cow's milk, which is responsible for unique flavor. Goat milk may be processed into yogurt drink as functional foods (Hassan et al., 2014). Yogurt is a dairy product with a rich nutritional value and contains high source of bioactive peptides with antioxidant activity that are produced during fermentation (Nguyen and Hwang, 2016). Additional with antioxidants would improve the functionality and acceptability of consumers (Wibawanti and Rinawidiastuti, 2018).

Recently, yogurt products are developed with natural sources of antioxidants. Addition of mangosteen peel extract to yogurt drinks is possible to increase antioxidant activity. Mangosteen (Garcinia mangostana L.) is one of the most famous fruits in Indonesia. The extracts from Mangosteen are known as antimicrobial and antioxidant. Mangosteen plants contains natural antioxidant constituents such as phenolic compounds (Zarena and Sankar, 2011). They have been widely used as a traditional medicine (Vishnu et al., 2010).
Several studies have been shown that phenol compound in mangosteen have remarkable biological activity. Therefore, the aim of the current study was to assess antioxidant activity (total phenol, antioxidant activity, and TBA value) of yogurt with the addition of mangosteen peel.

\section{Materials and Methods}

The yogurt samples were manufactured in laboratory, using the following raw materials: goat milk, lactic bacteria cultures and mangosteen rinds. Fresh goat milk was obtained from "Peranakan Etawah" breed $(\mathrm{PE})$ at Lurisae Farm, Loano, Central Java Province. Yogurt starter was composed of Lactobacillus acidophilus, Lactobacillus bulgaricus, and Streptococcus thermophillus. Mangosteen rinds were provided from local markets Kaligesing, Purworejo, Indonesia.

The study was conducted from March-December 2018. The raw milk was divided into four groups. The production of yogurt drink were made by fresh goat milk. The goat milk was pasteurized at $71^{\circ} \mathrm{C}$ for 15 seconds. After it was cooled down to $\pm 45^{\circ} \mathrm{C}$, pasteurized milk was 
inoculated with $2 \%$ yogurt starter. The samples were incubated at $38^{\circ} \mathrm{C}$ until coagulation and fortification with mangosteen peel/rind extract with various concentrations. The yogurt then were stored at $4^{\circ} \mathrm{C}$ until further analysis was performed.

The mangosteen was selected from fresh fruits and cleaned by water. The making of mangosteen rind extract was done by selecting the non-physically damage only mangosteen rind. As much as $200 \mathrm{~g}$ of mangosteen peel then was added by 1 liter of distilled water and homogenized. Filtration was done with filter paper. Centrifugation at speed of $6000 \mathrm{rpm}$ for 10 minutes was done to obtain mangosteen rind extract (Wibawanti et al., 2018)

The extract solution $(50 \mathrm{mg} / \mathrm{ml} ; 1 \mathrm{ml})$ was mixed with Folin-Ciocalteu reagent ( $5 \mathrm{ml}$, previously diluted with water 1:10, v/v) and sodium carbonate $(75 \mathrm{~g} / \mathrm{l}, 4 \mathrm{ml})$. The tubes were mixed for $15 \mathrm{~s}$ and allowed to stand for 30 min at $40^{\circ} \mathrm{C}$ for colour development. Absorbance was then measured at $730 \mathrm{~nm}$ in a spectrophotometer. The total phenolic content was expressed as gallic acid equivalent in $\mathrm{mg}$ per gram of dry extract.

The DPPH radical scavenging capacity of yogurt drink was determined according to the method of Mangla et al. (2010) with some modifications. Various dilutions of yogurt drink by mangosteen rind extract were made with various concentrations. Each of concentration was taken as $1 \mathrm{ml}$. In $5 \mathrm{ml}$ volumetric flasks, addition $2 \mathrm{ml}$ of DPPH solution (0.1 mM DPPH in methanol), $7 \mathrm{ml}$ of Methanol was done and incubated at $37^{\circ} \mathrm{K}$ for $30 \mathrm{~min}$. A standard radical scavenging activity curve was prepared by Butyrate Hydroxyl Toluene (BHT) of diluted DPPH. The absorbance was measured at $517 \mathrm{~nm}$. All treatments were done in triplicate. $\mathrm{IC}_{50}$ value was determined from the curve between percentage inhibition and concentration.

TBA value was determined using the method described by Nkhata et al., (2015) with modification. Five gram of yogurt drink sample was prepared. Yogurt was put in Erlenmeyer flask. It was added with $25 \mathrm{ml}$ of $10 \%$ TCA solution to sample. The flask were shake frequently for four minutes. The entire content was separated using filter paper or centrifuge until clear filtrate was obtained. Then $1 \mathrm{ml}$ was pipetted into the flask. The sample was added with $5 \mathrm{ml}$ of $0.02 \mathrm{mM}$ TBA. The sample was heated in boiling water for 45 minute in water bath. The sample was cooled under running water and diluted with $10 \mathrm{ml}$ distilled water. The antioxidant activity was evaluated by measuring the absorbance at $530 \mathrm{~nm}$ using spectrophotometer

Statistical analysis were performed by SPSS programme. All result was collected in a completely randomized design using analysis of variance (ANOVA) for each experiment each experiment was analysed then using Least Significant Differences (LSD) and Duncan with significance level of 0.05 .

\section{Results and Discussion}

The presence of phenolic compound in yogurt drink with mangosteen rind extract was detected. Total phenol content of yogurts drink with mangosteen rind extract were shown in Figure 1. The presence of mangosteen rind extract showed no significant differences in total phenol content $(p>0.05)$. The value of phenol of yogurt drink has increased by mangosteen rind extract. The highest total phenolic content in yogurt drink was found in $3 \%$ addition mangosteen rind extract. The total phenol content in the control yogurt was 5.14.

The research of total phenol content varied in yogurt depending on the level extract of mangosteen rind extract. The differences in the total phenol content may be attributed to the presence of different extractable components. Starter bacteria cultures also contributed to the increase in antioxidant activity of fermented yogurt drink. The total phenol was correlated with antioxidant activity. Antioxidant activity was preserved during storage of yogurt drink. Liu et al. (2008) reported that the antioxidant activity was correlated with phenolic content. Phenolic content was responsible to the flavor, color and oxidative stability of fresh and processed products (Luzia et al., 1997).

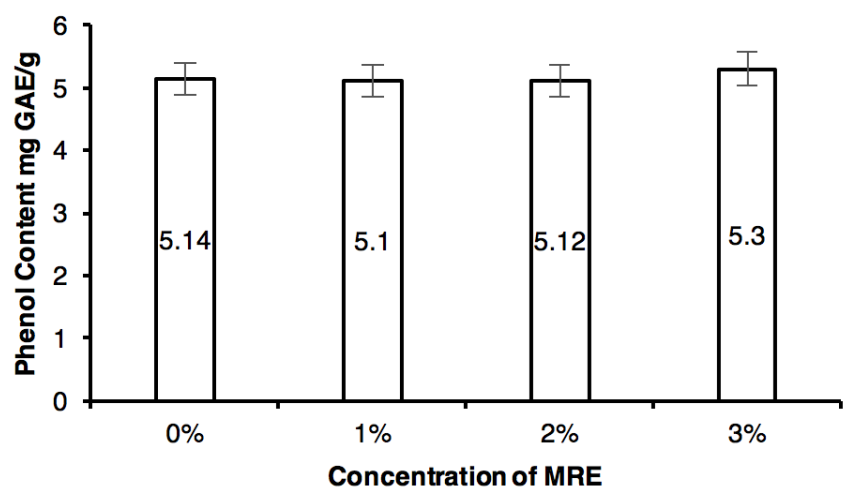

Figure 1. Total phenol content of yogurt drink with mangosteen rind extract

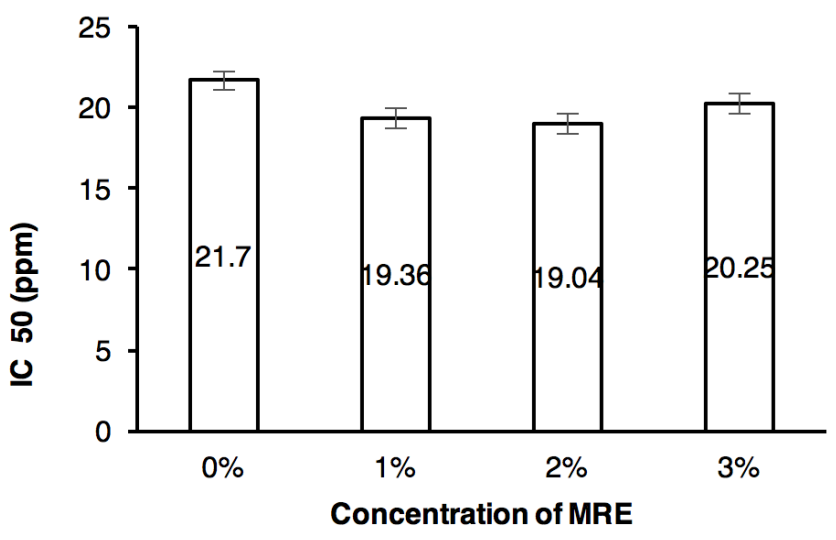

Figure 2. $I_{50}$ of yogurt drink with mangosteen rind extract

The scavenging of DPPH free radicals was used for measuring the antioxidant activity (Chaverri et al., 2008). Antioxidant activity is a molecule that inhibits the oxidation of other molecules caused by free radicals. Figure 2 shows the antioxidant content of yogurt drink added with different level of mangosteen rind extract. The antioxidant activity $\left(\mathrm{IC}_{50}\right)$ was exhibited $5.14 ; 5.1$; 5.12 and 5.3 for, 1,2 and $3 \%$ treatments, respectively. In this research, control showed $\mathrm{IC}_{50}$ value higher than the with mangosteen rind extract. It means yogurt drink with 
mangosteen rind extract had higher radical scavening activity than control.

The antioxidant activity in yogurt drink might result from the bioactive compound of the mangosteen rind extract. The ability of antioxidant activity may be due to hydrogen atoms of the phenolic hydroxyl groups. Wibawanti et al., (2018) reported that each part of mangosteen (peel, leaves, and bark) showed antioxidant activity with various $I_{50}$ value. Arazo et al., (2011) reported the antioxidant activity of phenolic acids present in mangosteen was due to major secondary metabolite xanthones.

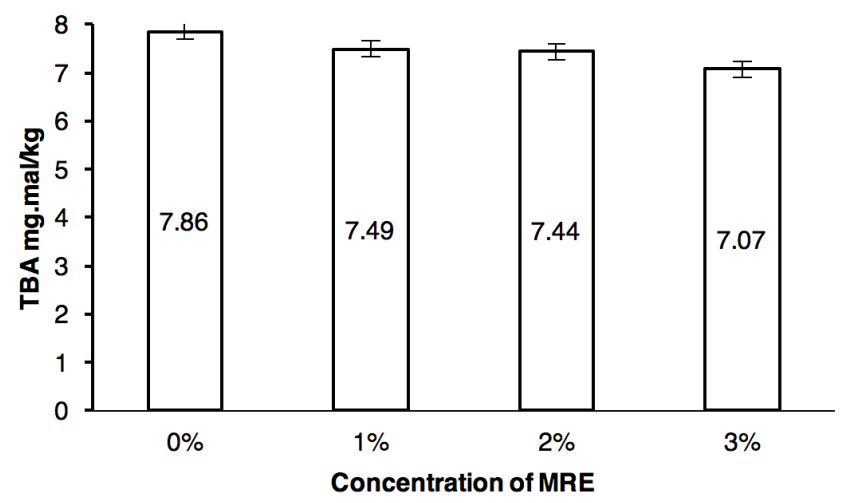

Figure 3. TBA of yogurt drink with mangosteen rind extract

Thiobarbituric Acid (TBA) Value

Yogurt drink with mangosteen rind extract showed significant differences $(p<0.05)$ among treatments as shown in Figure 3. Yogurt drink with 3\% of mangosteen rind extract were founded to be the lowest TBA values. The control was showed the highest TBA value $(7.85$ $\mathrm{mg} . \mathrm{mal} / \mathrm{kg}$ ). TBA value of yogurt drink of mangosteen rind extract was $7.48 ; 7.44 ; 7.06, \mathrm{mg} . \mathrm{mal} / \mathrm{kg}$ for, 1,2 and $3 \%$ treatments, respectively. This study indicates that yogurt drink by mangosteen rind extract decreased lipid oxidation. This may be due to phenol activity that changes fat structure. Dobarganes and Velasco (2002) reported the changes may occur in the structure of lipid and have been known as rancid leading to the formation of an unpleasant flavor and the loss of nutritional value.

\section{Conclusion}

The addition of mangosteen rind extract on the yogurt drink contributed to the increase in antioxidant activity. The phenol content of yogurt drink increased by mangosteen rind extract addition. Based on the $\mathrm{IC}_{50}$ and TBA value, mangosteen rind extract had potential use hinder the rancidity in yogurt.

\section{Acknowledgments}

This research was supported by The Ministry of Research, Technology, and Higher Education of Republic Indonesia ("Penelitian Dosen Pemula"). It also supported by LPPM ("Lembaga Penelitian dan Pengabdian Masyarakat"), Muhammadiyah University of Purworejo.

\section{References}

Arazo, M., Bello, A., Rastrell, L., Monteller, M., Delgado, L., Panfet, C. 2011. Antioxidant properties of pulp and peel of yellow mangosteen fruits. Emirates Journal of Food and Agriculture 23(6):517-524.

Chaverri, J.P., Rodriguez, N.C., Ibarra, M.O., Rojas, J.M.P. 2008. Medical properties of mangosteen (Garcinia mangostana). Food and Chemical Toxiology 46: 3227-3239. DOI: 10.1016/ j.fct.2008.07.024.

Dobarganes, M.C., Velasco, J. 2002. Analysis of lipid hydroperoxide. European Journal of Lipid. Science and Technology 104:420-428. DOI:10.1002/14389312(200207)104:73.0.CO;2-N.

Hassan, F.A.M., Abbas, H.M., Abd El-Gawad, M.A.M., Enab, A.K. 2014. Goats dairy products as potentially functional food. Life Science Journal: 11 (648-657).

Liu, X., Zhao, M., Wang, J., Yang, B., Jiang, Y. 2008. Antioxidant activity of methanolic extract of emblica fruit (Phyllanthus emblica L.) from six regions in China. Journal of Food Composition and Analysis 21: 219-228.

Luzia, M. R., Paixao, D. A., Marcilio, K.C.C., Trugo, L.C., Quinreiro, L.M.C., De Mariq, C.A.B., Effect of 5caffeoylquinic acid on soybean oil oxidative stability. International Journal of Food Science and Technology 32:15-19. DOI: 10.1046/j.13652621.1997.00370.x.

Mangla, M., Shuaib, M., Jain, J., Kashyap, M. 2010. In-vitro evaluation of antioxidant activity of Curcuma caesia roxb. International Journal of Pharmaceutical Sciences and Research 1(9):98-102. DOI:10.13040/IJPSR.0975-8232.1(9-S).98-02.

Nkhata, S.G., Ustunol, Z., Menevseoglu, A. 2015. Iron fortification of yogurt and pasteurized milk. Journal of Nutritional Health \& Food Science. 3(3): 1-12. DOI:10.15226/jnhfs.2015.00142.

Nguyen, L., Hwang, E.S. 2016. Quality characteristics and antioxidant activity of yogurt supplemented with aronia (Aronia melanocarpa) juice. Preventive Nutrition and Food Science 21(4):330-337. DOI: 10.3746/pnf.2016.21.4.330.

Vishnu, V.P., Jainu, M., Mohan, S.K., Saraswathi, P., Gopan, C.S. 2010. Antimicrobial activity of pericarp extract of Garcinia mangostana lin. International Journal of Pharma Sciences and Research. 1(8):278-281.

Wibawanti, J.M.W., Rinawidiastuti. 2018. Physical and sensory properties goat milk yogurt drink fortified by mangosteen rind (Garcinia mangostana lin.). Teknologi Hasil Ternak (JITEK). 13(1): 27-37. (In Bahasa Indonesia). DOI:10.21776/ub.jitek. 2018.013.01.3.

Wibawanti, J.M.W., Rinawidiastuti, Arifin, H.D., Zulfanita. 2018. Improving characteristics of goat milk yogurt drink fortified by mangosteen rind (Garcinia mangostana lin.) extract. IOP Conference Series: Earth and Environmental Science 102 (1): 012008. DOI :10.1088/1755-1315/102/1/012008.

Zarena, A.S., Sankar, K.U. 2011. Phenolic acids, flavonoid profile and antioxidant activity in Mangosteen (Garcinia Mangostana L.) pericarp. Journal of Food Biochemistry 627-633. DOI:10.1111/j.17454514.2011.00575.x 